\title{
Clinical and Biochemical Changes Induced by Alcohol at the Patients with Mental IIIness
}

\author{
VICTOR GHEORMAN ${ }^{1}$, VENERA CRISTINA DINESCU2, OANA CRICIOTOIU³, DIANA STANCA ${ }^{3}$, VERONICA CALBOREAN $4 *$, \\ ADRIAN MITA ${ }^{5}$, ALINA MISCOCI ${ }^{6}$, DRAGOS VIRGIL DAVITOIU', VLAD DUMITRU BALEANU ${ }^{8}$, RAMO NA-MIHAELA NEDELCUTA9, \\ SORIN NICOLAE DINESCU ${ }^{10}$, ANDA LORENA DIJ MARESCU ${ }^{11}$, DANIEL-IULIAN VOICULESCU ${ }^{12}$, ION UDRISTOIU ${ }^{1}$ \\ University of Medicine and Pharmacy of Craiova, Psychiatry Department, Neuropsychiatry Hospital of Craiova, 24 Potelu Alley, \\ 200473, Craiova, Romania \\ ZUniversity of Medicine and Pharmacy of Craiova, Health Promotion and Ocupational Medicine Department, 2 Petru Rares Str., \\ 200349, Craiova, Romania \\ ${ }^{3}$ University of Medicine and Pharmacy of Craiova, Neurology Department, Neuropsychiatry Hospital of Craiova, 99 Calea \\ Bucuresti Str., 200473, Craiova, Romania \\ 4University of Medicine and Pharmacy of Craiova, Cardiology Department, 2 Petru Rares Str., 200349, Craiova, Romania \\ ${ }^{5}$ University of Medicine and Pharmacy of Craiova, Internal Medicine Department, Filantropia Hospital of Craiova, 1 Filantropiei \\ Str., 200143, Craiova, Romania \\ שUniversity of Medicine and Pharmacy of Craiova, Internal Medicine Department, 2 Petru Rares Str., 200349, Craiova, Romania \\ University of Medicine and Pharmacy of Bucharest, Surgery Department, Clinical Emergency Hospital Sf. Pantelimon Bucharest, \\ 340-343 Pantelimon Road, 021659, Bucharest, Romania \\ ¿University of Medicine and Pharmacy of Craiova, Surgery Department, Clinical Emergency Hospital Sf. Pantelimon Bucharest, \\ 340-343 Pantelimon Road, 021659, Bucharest, Romania \\ ${ }^{9}$ University of Medicine and Pharmacy of Craiova, Pediatrics Department, 2 Petru Rares Str., 200349, Craiova, Romania \\ 10University of Medicine and Pharmacy of Craiova, Epidemiology and Primary Health Care Department, 2 Petru Rares Str.,200349, \\ Craiova, Romania \\ ${ }^{11}$ University of Medicine and Pharmacy of Craiova, Obstretics-Gynecology Department, Filantropia Clinical Hospital of Craiova, \\ 1 Filantropiei Str., 200143, Craiova, Romania \\ ${ }^{12}$ University of Medicine and Pharmacy Carol Davila Bucharest, Department of Surgery Universitary Emergency Hospital \\ Bucharest, 169 Splaiul Indepenei, 050098, Bucharest, Romania
}

Alcoholism use disorders are very frequent present all over the world. The use of alcohol is responsable for many behavioral symptoms like impulsivity, violence, depressive mood and anxiety. The aim of our research was to find the clinical and the biochemical changes induced by alcohol at the patient with mental illness.

Key words: alcoholism, mental illness, biochemical parameters

Alcoholism represents one of the most difficult problem, affecting an important number of people worldwide.

Alcoholism could be considered a bad custom or a real disease. It can be defined as an continue drinking use despite the negative consequences [1].

It is well-known that the use of alcohol is influenced by many factors . In some countries, this behaviour is a cultural factor, people use to drink to celebrate a happy eventor an important day. In this case we can say that the use of alcohol get the importance of a family tradition.

Many international studies proves strong correlations between use of alcohol and cardiovascular disorders. Alcohol consumption is a trigger of cardiovascular affectation. An important percent of drinking alcohol patients presented the elevation of ST segment and the rate of miocardial infarction is higher comparing with the rest of the people [2-4].

The risk of sudden death is higher at the patients diagnosticated with cardio-hepatic comorbidities. At this group of patients the use of alcohol for a long period of time increased much more the miocardiac infarction risk [5-7].

The use of alcohol is also associated with many methabolism disorder, especially in glucid disorder. The patients diagnosticated with diabetes mellitus presented a high risk of complications triggered by alcohol. This complications might me neurologicaly, oftalmologicaly or hidro-electrolytic [ 8-10].

Regarding mental symptoms it is well-know that the use of alcohol is often asociated with behavioural changes. Many studies highlights strong corelations betw een use of alcohol and impulsivity [11-12] .

The alcohol is very frequent used by the people in order to decrese depressive mood or anxiety, but unfortunatly the anxiolytic effect of alcohol is just temporary and the alcohol withdrawal is often associated with incresed level of anxiety and with the presence of negative sensations $[13-15,38]$.

Moreover, the use of alcohol decreases the quality of life of the patients in general and of the patients with mental illness in special. The level of stress is also incresease and the prognosis of the disorder is alterated by alcohol, too [16-18].

\section{Experimental part}

The aim of the study

Our study was developt between 1st March and 30th November 2018, in Neuropsychiatric Hospital of Craiova Romania.

A number of 89 subjects were involved in this research. All of the subjects were informed about the aim of the study and the participaton was optionaly. 
The criteria for including a patient in our study were:

-To be diagnosticated with a mental illness in the past

-To be admited to the hospital in the perioad of our study

-To be known as an alcohol addicted.

We recorded demographic data as age, gender, envinromental area, occupational status, level of education, personal physiological history, somatic comorbidities history (cardiovascular, neurological, gastrointestinal, hepapatological, renal disorders etc.). Patients were questioned about smoking others customs like smoking, gambling or use of other substances.

The following laboratory blood counts were performed: hemoglobine, serum creatinine, serum urea, total cholesterol, HDL-cholesterol, triglycerides, uric acid, glicemya, liver enzymes.

All the patients have benefited by many medical examination like cardiology exam, internal medicine , neurology etc. in order to find any somatic complication caused by alcohol, being well-known that alcohol use is responsable for a lot of disorders.

The main aim of our research was to find the most important behavioural and biochemical changes induced by alcohol at the patients diagnosticated with mental illness.

\section{Results and discussions}

The distribution of the subjects according to gender

We realised an analize of the distribution of our subjects according to demographic data as gender, age and geographic area.

As we can see from the following table and chart, more than $64 \%$ of the patients involved in study were men.

This results are quite predictible and corelated with the results from scientific literaature which proved that worldwide the use of alcohol is much frequent at men comparing with women [19-21] .

\begin{tabular}{|l|l|}
\hline gender & no \\
\hline men & 57 \\
\hline women & 32 \\
\hline
\end{tabular}

Tabel 1

DISTRIBUTION OF SUBJECTS BY GENDER

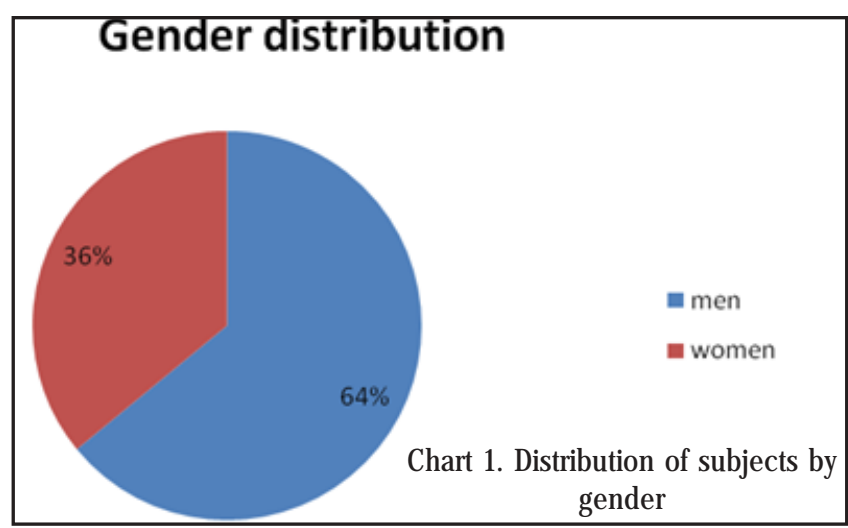

Regarding to the geographic area observed that the greatest percent of the patients are coming from the rural region of the country.

More than $80 \%$ of the subjects involved in our research are living in rural environment comparing with just 20\% who are coming from urban regions.

This results are also corelated with the literature, if we admited that this study was developt in Romania, a country which is one of the countries with a high level of use of alcohol per inhabitant.More than this, in Romania, as well as in the Central and EstEurope, use of alcohol represents, especially at the countryside, a cultural and socio-familial factor [22-23].

The distribution of the subjects according to geographic area is presented in table 2 and figure 2 .

\begin{tabular}{|l|l|}
\hline $\begin{array}{l}\text { Geographic } \\
\text { area }\end{array}$ & no. \\
\hline rural & 71 \\
\hline urban & 18 \\
\hline
\end{tabular}

Tabel 2

DISTRIBUTION OF SUBJECTS BY GEOGRAPHIC AREA

\section{Geographic distribution}

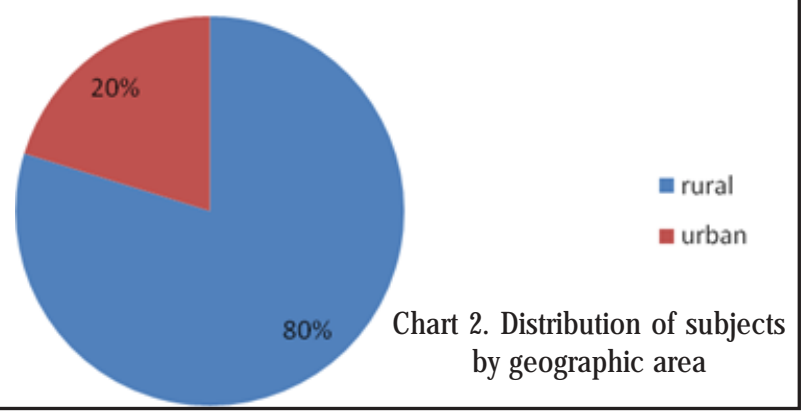

Age distribution shows us that 31 from 89 subjectes were between 40 and 49 years old. This group age represents the highest percent. We can say that the middle age people have the most dangerous behavior of using alcohol.

The second place is occupied by the subject with ages between 20 and 29 years old. This high percent registered for Romanian youths represents a serious alarm signal and an important criteria for developting more prevention programs in order to decrease the use of alcohol.

Distribution by age

\begin{tabular}{|l|r|}
\hline $\begin{array}{l}\text { Age } \\
\text { distribution }\end{array}$ & $\begin{array}{r}\text { age } \\
\text { distribution }\end{array}$ \\
\hline $20-29$ & 17 \\
\hline $30-39$ & 11 \\
\hline $40-49$ & 31 \\
\hline $50-59$ & 14 \\
\hline $60-69$ & 10 \\
\hline 770 & 6 \\
\hline
\end{tabular}

Tabel 3

DISTRIBUTION OF SUBJECTS BY AGE

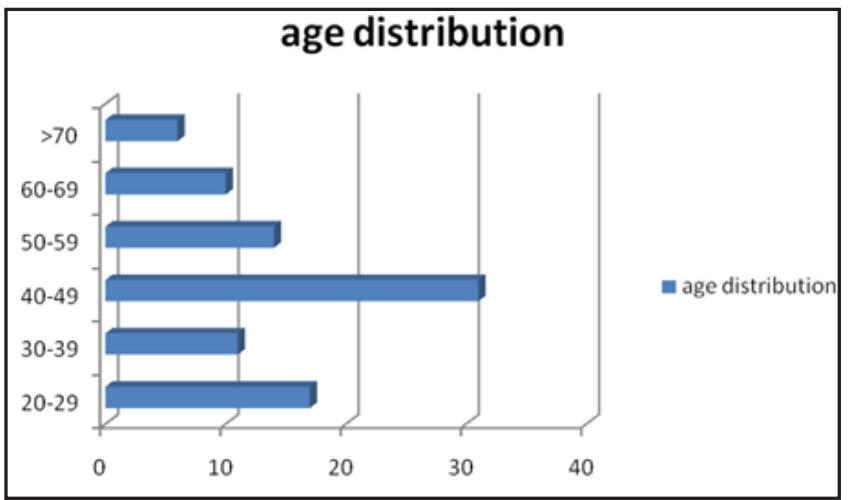

Chart 3. Distribution of subjects by age

It is well-known that use of alcohol is associated with several mental illness. In our study we observed that the most of the patients with alcohol addiction were diagnosticated with majore depressive disorder ( 49 subjects). A number on 16 patients with bipolar disorder 
and 15 patients with obsesive compulsive disorder presented high use of alcohol, comparing with just 2 patients with schizophrenia and 7 subjects dignosticated with dementia.

Distribution by psychiatric disorders

\begin{tabular}{|l|l|}
\hline psychiatric disease & $\begin{array}{l}\text { number of } \\
\text { subjects }\end{array}$ \\
\hline depressive disorder & 49 \\
\hline schizophrenia & 2 \\
\hline bipolar disorder & 16 \\
\hline dementia & 7 \\
\hline OCD & 15 \\
\hline
\end{tabular}

Tabel 4

DISTRIBUTION BY PSYCHIATRIC DISORDERS

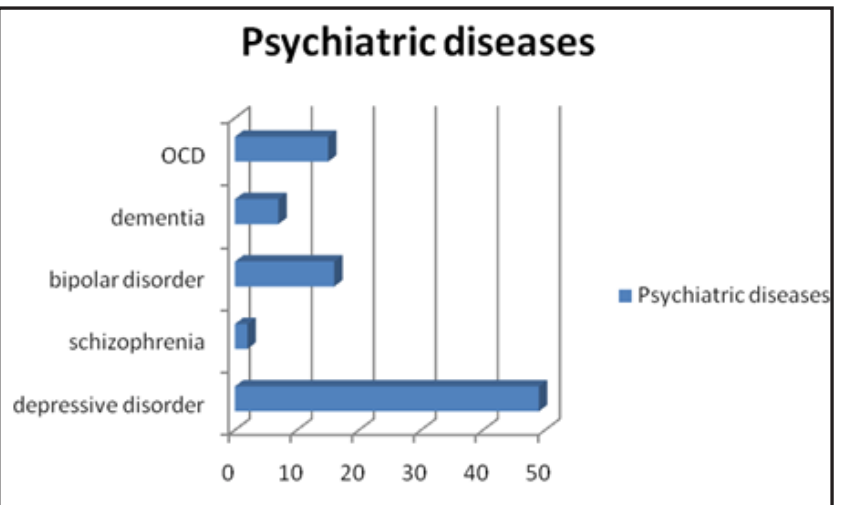

Chart 4. Distribution by psychiatric disorders

Regarding the somatic comrbidities associated with alcohol use we can see in our study that the consumption of alcohol is responsable for many disfunctions of a couple of organs.

Around $40 \%$ patiens(35subjects) were before diagnosticated with at least one of cardio-vascular disorder. The cardiovascular disorders are followed by hepatic diseases(29 patients) and neurological disorders(17 subjects).

The predominance of cardiovascular diseases is corelated with the highest incidence of cardiovascular disorder in normal population and it is very important to initiate very early the specific tratement. Changing the life style might be useful for a large number of patient, but for a high percent of the people diagnosticated with cardiovascular disorder is it necessary an antiarrhythmic treatment correlated with cardiovascular intervention [2426].

Tabel 5

DISTRIBUTION BY SOMATIC COMORBIDITIES

\begin{tabular}{|l|l|}
\hline $\begin{array}{l}\text { somatic } \\
\text { comorbidities }\end{array}$ & number \\
\hline cardio-vascular & 35 \\
\hline neurological & 17 \\
\hline hepatic disease & 29 \\
\hline renal disease & 8 \\
\hline
\end{tabular}

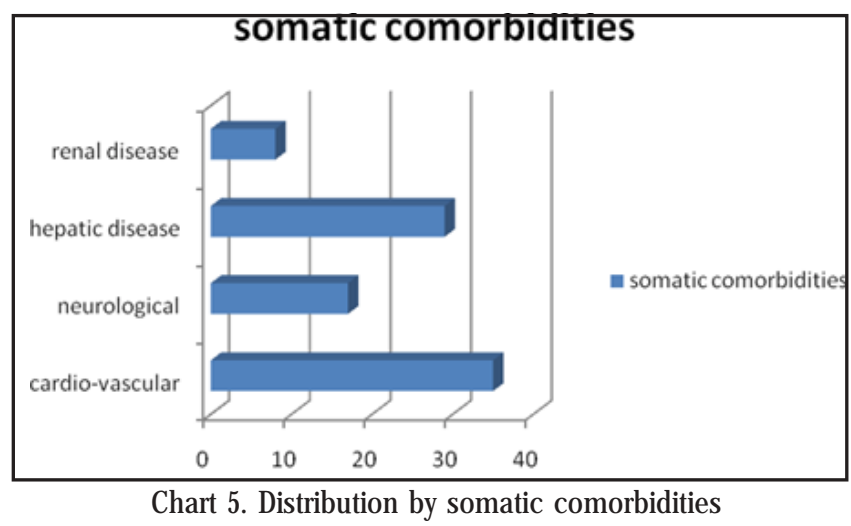

Distribution by somatic comorbidies

Studing the alterations of blood parameters, we can highlight that liver enzymes represented the most affected blood parameter. The level of liver enzymes were incresead at 88 from 89 patients. Also the lipidic was very affected, more than half of patients registered high levels of triglycerides and cholesterol. The methabolism alteration produced by alcohol represented one of the worsteffect of this addiction [27-32].

\begin{tabular}{|c|c|}
\hline cholesterol & 3 \\
\hline triglycerides & 7 \\
\hline liver enzymes & 8 \\
\hline blood glucose & 7 \\
\hline
\end{tabular}

Tabel 6

BLOOD PARAMETERS ALTERATIONS

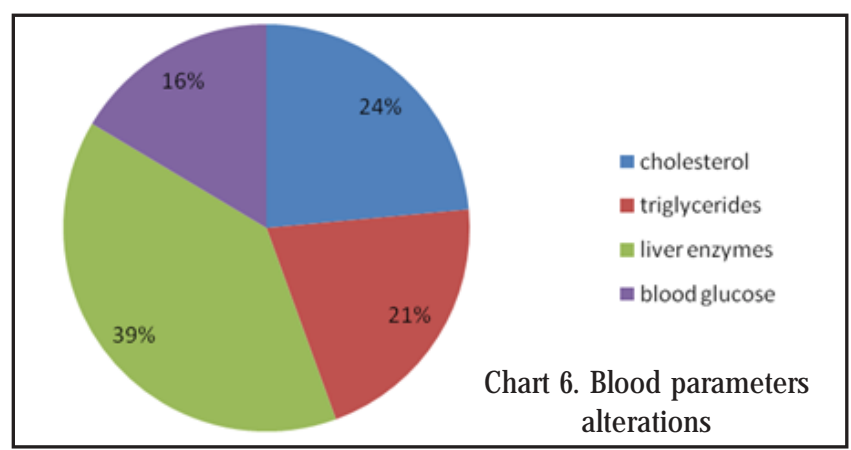

This results, show us again the negative effect of alcohol over all the metabolism and over all organs and systems [33-34].

\section{Conclusions}

Alcoholism represent one of the most frequent used substance with several effectes among people from every country.

In our study we wanted to highligh the clinical and the biochemical alterations produced by alcohol at the mental ill patients admited in the Psychiatric Department.

The highest percent was represented by men, between 40 and 49 years old, from rural regions of the country, but we cannot underestimat the risk of alcoholism at the women. Dates from literature attest the negative effects produced by alcohol especially at the pregnant women. [35-37]

The most patients diagnosticated with alcoholism problems were diagnosticated with depressive disorders and a great number of them had cardiovascular comorbidities. 
The biochemical status of the blood was aslo disturbed by alcohol, more than $90 \%$ of the patients presented an incresed level of livel enzymes and half of the subjects involved in the study registered alteration of lipidic metabolims.

It is very important to implement a high number of national programs to prevent and to decrease the use of alcohol. It is also necessary a better colaboration between doctors from different departments in order to prevent and to treat the effects or the complications of alcohol use.

\section{References}

1.FULTON, T.C., RYAN,P.V. Mechanisms of neuroimmune gene induction in alcoholism, Psychopharmacology (2016), Volume 233, Issue 9, pp 1543-1557

2.GOWDA, R.M., KHAN I.A, VASAVADA, B.C, SACCHI, T.J . Alcoholtriggered acute myocardial infarction., Am J Ther. 2003 JanFeb; $10(1): 71-2$

3.CALBOREAN, V., GHEORMAN, V., ISTRATOAIE, O., MUSTAFA, R.E.,COJOCARU, P.A., ALEXANDRU, D.O., GALCEAVA, O., MITA, A.,MISCOCl, S.A., AL NAMAT, R., GHEONEA,D.I. QT interval analysis in patients with chronic liver disease, Rev. Chim. (Bucharest), 69, no. 5, 2018, p.1134-1138.

4.VLADU, M. RADU, L. GIRGAVU, S.R., BALEANU, V., CLENCIU, D. , ENE, C.G. SOCEA, B., MAZEN, E., CRISTEA, O.M, MOTA, M., TENEA COJAN, T. S., An Easy Way to Detect Cardiovascular Risk, Rev.Chim. (Bucharest) 69, no.11, 2018, p. 4229-4232

5.CALBOREAN, V., MISCOCI, S. A., ISTRATOAIE, O., GALCEAVA , O.,ALEXANDRU, D.O., GUTA, M.M., GHEORMAN, V., PADUREANU, V., FORTOFOIU, C.M., DIJMARESCU, A.L., GHEONEA, D.I., Correlation Between Liver Cirrhosis and Risk of Cardiac Arrhythmias, Rev Chim(Bucharest), 69, no 6, 2018, p. 1527-1532.

6.GHEORMAN,V., MILITARU., CALBOREAN,V., GHEORMAN, L.M.,CHIRITA, A.L., MITA, A., GALCEAVA, O., GHEORMAN, V., STANCA, D.,UDRISTOIU, I., Clinical and biochemical consideration regarding stress and arrhytmic risk in patients with chronic viral liver diseases, Rev Chim. (Bucharest),69, no. 4, 2018, p.881-885.

7.CALBOREAN, V., GHEORMAN, V.,CONSTANTIN, C. ISTRATOAIE, O. Venous Thromboembolism Secondary to Adult-Onset Still's Disease: a Case Report, J ournal of Cardiovascular Emergencies, 2018, 4, nr.2,p. 101-105.

8.ENE,C.G.,ROSU,A., GHEORMAN,V., CALBOREAN,V., TENEA COJAN,T.S., ROGOVEANU,O.C., VLADU,M.I., RADU, L. Incidence of Osteoporosis and the Risk of Fracture in Patients with Rheumatoid Arthritis Undergoing Corticosteroid Treatment, Rev. Chim. (Bucharest), 69, no. 7, 2018, p.1851-1854.

9.VLADU,I.M., RADU,L., GIRGAVU ,S.R., TENEA COJAN, T.S., ENE, C.G., CALBOREAN, V., GHEORMAN, V., CLENCIU,D. Alteration of Glucidic Metabolism in Relation with Visceral Adiposity Index, Rev Chim (Bucharest), 69,no 9, 2018, p.2479-2481.

10.ZLATIAN,O.,BALASOIU,A.T., BALASOIU,M.,CRISTEA,O., DOCEA,A.O.,MITRUT,R., SPANDIDOS,D.A., TSATSAKIS, A.M., BANCESCU, G.,CALINA, D., Antimicrobial resistance in bacterial pathogens among hospitalised patients with severe invasive infections. Experimental And Therapeutic Medicine 2018 Dec, 16(6): 4499-4510.

11.DICK, D.M., SMITH,G., OLAUSSON,P., SUZANNE,H., MITCHELL ,R.F. LEEMAN, S, O'MALLEY, S., SHER, K. REVIEW: Understanding the construct of impulsivity and its relationship to alcohol use disorders, Addiction Biology, Volume 15, Issue2, April 2010, Pages 217-226

12.IONICA,F.E., MOGOANTA,L., NEGRES,S, BEJENARU, L.E, CRISTEA,O.M, BADEA,O., BEJENARU, C. Comparing the antifibrotic effect on the liver of Telmisartan and Pentoxifylline, in a Wistar rat experimental model. Romanian Journal of Morphology and Embryology 2017, 58(4):1237-1248.

13.GAJ BHIYE, S.V., TRIPATHI, R.K.,PETARE, A.,POTEY, A.V.,SHANKAR, A. Minocycline in Alcohol Withdrawal Induced Anxiety and Alcohol Relapse in Rats, Current Clinical Pharmacology, Volume 13, Number 1, 2018, pp. 65-72(8)

REV.CHIM. (Bucharest) $\bullet 70 \diamond$ No. 4 2019
14.AVRAMESCU,C., BICIUSCA,V., DAIANU,T., TURCULEANU,A., BALASOIU, M., POPESCU, S.N., IONETE,O., SIMIONESCU,C., Cytokine panel and histopathological aspects in the systemic lupus erythematosus. Romanian Journal of Morphology and Embryology 2010, 51(4):633-640.

15.CALBOREAN,V., GHEORMAN,V., AL NAMAT, R., CAZACU,I. M., VARJU,P., GEDE, N., STREBA,T.C., VERE, C.C., GHEONEA,D.I., GHEORMAN, V., LUNGULESCU, C., LUNGULESCU, C., V. The Association Between Stress Level and Laboratory Parameters, Sex, Age and Stage Disease in Patients with Digestive and Bronchopulmonary Neoplasms, Rev. Chim. (Bucharest), 68, no 12, 2017, p.30103014.

16.CHIMORGIACHIS,A.,CONSTANTIN,M.D.G.,UDRISTOIU,T., PIRLOG,M.C., UDRISOIU,I.Weight gain in patients with schizophrenia and atypical antipsychotic treatment - neurobiological correlations. JOURNAL OF NEURAL TRANSMISSION, 114, issue 7, 2007, p. CXXCXX.

17.BUICU, G.E., GRECU, M.G., SALCUDEAN, A.,GRECU, I.G., MARINESCU, C., NIRESTEAN, A.,TURLIUC, S., HADAREANU, V., UDRISTOIU, I. Evaluation of elder physical abuse. EUROPEAN PSYCHIATRY, 41, 2017, p S583-S584.

18.DELKER,E., BROWN, Q., HASIN,D.S. Alcohol Consumption in Demographic Subpopulations An Epidemiologic Overview Alcohol Res. 2016; 38(1): 7-15.

19.TRASCA, S.P., FLORESCU, C., DINESCU, V.C.,PUIU, I., DINESCU, S.N., TUDORASCU, D.R., BICA, C., VASILE, R.C., ROMANESCU, F.M., BUNESCU, M.G., CIOATERA, N., GOANTA, E.V., Rev. Chim. (Bucharest), 2018, 69, no.12, p.3600-3604.

20.ZADARKO-DOMARADZKA,M.,BARABASZ,Z., SOBOLEWSKI, M., NIZIO-BABIARZ,E., PENAR-ZADARKO,B., SZYBISTY, A., E.ZADARKO, Alcohol Consumption and Risky Drinking Patterns among College Students from Selected Countries of the Carpathian Euroregion, BioMed Research International, Volume 2018, Article ID 6084541,9 pages

21.ZORILA,M.V.,TOLESCU,R.S.,ZORILA,G.L.,DIACONU,M, UNGUREANU, B.S., ZAVOI,R.E., CRISTEA,O.M., CHEN, F.I. Liver hydatid cyst - cause for violent death. Case presentation. Romanian Journal of Morphology and Embryology 2018, vol.59(4):1219-1224.

22.MARINAS,A.E, CIUREA,P., MARGARITESCU,C.,COTOI, O.S. Expression of Epidermal Growth Factor (EGF) and its receptors (EGFR1 and EGFR2) in chronic bronchitis, Rom. J. Morphol. Embryol., Vol.53, Issue 4, pg.957-966

23.ZLATIAN,O., BALASOIU,A.T., BALASOIU, M., CRISTEA,O., DOCEA,A.O., MITRUT,R. SPANDIDOS,D.A.,. TSATSAKIS,A.M., BANCESCU,G., CALINA, D. Antimicrobial resistance in bacterial pathogens among hospitalised patients with severe invasive infections. Experimental And Therapeutic Medicine 2018 Dec, 16(6): 4499-4510.

24.CALBOREAN, V., CIOBANU, D., MIREA, S.C., GALCEAVA, O.,GHEORMAN, V., PADUREANU, V., FORTOFOIU, C.M., FORTOFOIU,M., MITA, A., DINESCU, S.N., MISCOCI, S.A., DINESCU, V.C. Benefit of Cardiac Resynchronization Therapy in Patients with Heart Failure. Rev. Chim. (Bucharest), 69, no. 9, 2018, p.2461-2464. 25. PUIU,I.,ALBU,C.V., TARTEA,E.A., CALBOREAN,V., GHEORMAN,V., DINESCU,S.N., VASILE,R.C., DINESCU,V.C., BICA, E.C., ROMANESCU, F.M., TUDORASCU,D.R. Relationships Between Glial Enteric Cells, Beta-cell Signaling and Tumor Proliferative Activity in Patients with Colorectal Neoplasia, Rev Chim (Bucharest), 69, no 10, 2018, p. 2744 2748.

26.GHEORMAN,V.,CHIRITA,A.L.,DUMITRESCU,E.M.,ROGOVEANU,I., ISTRATOAIE,O., GHEORMAN,V.,PANA,R.C. Particularities of associating viral hepatitis with pregnancy and mental disorders, Rom J MorpholEmbryol 2016, 57(1): 45-50.

27.BALEANU, V.D., CONSTANTIN, D.V., PASCAL, A., ALEXANDRU, D.O., BOBIC, S., SOCEA, B ., MANDA, A.L., DAVITOIU, D., DIJ MARESCU, A.L., GEORGESCU, I., MIREA, C.S. Use of Synthetic Protetic Materials in Surgical Abdominal Defects Analysis of the Advantages and Lack of the Liechtenstein Method. Rev. Chim.

(Bucharest), 69, no 7, 2018, p 1740-1743.

http://www.revistadechimie.ro 
28.NOVAC, M.V., NICULESCU, M., MANOLEA, M.M., DIJ MARESCU, A.L., ILIESCU, D.G., NOVAC,M.B., ROTARU,L.T, STOENESCU, M.F., TABACU, M.C., TUDORACHE, S., BUSUIOC, C.J . , GHEONEA, I.A. Placental findings in pregnancies complicated with iugrhistopathological and immunohistochemicalanalysis.Rom J MorpholEmbryol , 2018, vol 59, p. 715-720.

29.STOENESCU,V.E., NICULESCU,M., NOVAC,L., MANOLEA, M.M., TOMESCU, P.I., DIJ MARESCU, A.L., NOVAC, M.B., TUDORACHE, S., ILIESCU, D.G .Immunohistochemical reaction of the glandular epithelium in endometrial hyperplasia compared to endometrial carcinoma. Rom J MorpholEmbryol, 2017, vol 58, 791-800.

30.SIMINEL,M.A., GHEONEA,C., STANESCU,M.R.,COMANESCU, A.C., DIJ MARESCU, A.L., NEAMTU, S.D., COTOI, B.V., NEDELCUTA, R.M., NICULESCU, E.C.Velamentous insertion of the umbilical cord vessels with vasa praevia - a case report .Rom J MorpholEmbryol, 2015, vol 56, 301-308.

31.RADU,L., CARSOTE, M., PREDESCU,A.M., TENEA-COJ AN,T.S.T., SOCEA,B., BALEANU,V.D. POPESCU,M., IONOVICI,N., ALBULESCU, D.M.- Biochemical parameters in patients using teriparatide 32.SOCEA, B., RADU, L., CLENCIU, D. , TENEA COJAN, T. S, BALEANU, V. ,ENE, C.G., GIRGAVU, S.R., VLADU, I.M. The Utility of Visceral Adiposity Index in Prediction of Metabolic Syndrome and Hypercholesterolemia, Rev.Chim.(Bucharest) 69, no. 11, 2018, p. 3112-3114
33.VLADU, M., CLENCIU,D., EFREM, I.C., FORTOFOIU,M.,AMZOLINI, A.,TUDORICA MICU,S., MOTA,M., FORTOFOIU, M.C. Insulin Resistance and Chronic Kidney Disease in Patients with Type 1 Diabetes Mellitus. Journal of Nutrition and Metabolism, vol. 2017, Article ID 6425359, 5 pages, 2017. doi:10.1155/2017/6425359

34. CRISTEA,O.M., AVRAMESCU, C.S., BALASOIU, M., POPESCU, F.D., POPESCU,F., AMZOIU, M.O. . Urinary tract infection with Klebsiella pneumoniae in Patients with Chronic Kidney Disease. Current Health Sciences J ournal 2017,43(2): 137-148.

35.FORTOFOIU,M., FORTOFOIU,M.C., COMANESCU,V., DOBRINESCU, A.C., PAduREANU,V., VERE, C.C., STREBA, C.T, CIUREA,P.L.. Hepatocellular carcinoma and metabolic diseases - histological perspectives from a series of 14 cases. Rom J Morphol Embryol. 2015;56(4):1461-5

36.VERE,C.C., NEAGOE,D., STREBA,C.T., PREJ BEANU, I., IANOSI,G., COMANESCU, V., PIRICI,D. Steatosis and serum lipid patterns in patients with chronic viral hepatitis: differences related to viral etiology. Rom J Morphol Embryol 2010; 51(3): 509-514.

37.STREBA, L.A.M., CARSTEA,D., MITRUT,P.,VERE, C.C.,DRAGOMIR,N., STREBA, C.T. Nonalcoholic fatty liver disease and metabolic syndrome: a concise review. Rom J Morphol Embryol 2008;49(1):13-20.

38. CHIVU, O.R., MEDERLE, O., SEMENESCU, A., et. al., Rev. Chim. (Bucharest), 69, no. 4, 2018, p. 875

$\overline{\text { Manuscript received: } 21.12 .2018}$ 